\title{
Australian invasion
}

Received (in revised form): 29 August 2007

\section{Anthony Klan}

is a senior property journalist with The Australian newspaper. He covers property trends, listed property trusts, residential property and corporate crime.

\section{Abstract}

Australia has the skills and the investment demands to catapult its best retail players into the world spotlight.

\section{Keywords:}

Australia, retail, shopping centres, investment

First published by Property Australia magazine, September 2007

Journal of Retail and Leisure Property (2007) 6, 291-293. doi:10.1057/palgrave.rlp.5100071

Capitalisation rates on retail assets are at or near peak levels in both the US and UK markets - with some even tipping a modest correction in UK values. But according to local key players, Australian investment in those markets will continue to rocket in the coming decade.

A growing shortage of quality local assets, Australia's burgeoning superannuation investment pool - disproportionately large by global standards - and offshore demand for Australian retail skills and design concepts will underpin that continued surging demand.

'Two Australian shopping centres are in the top ten owners in the US — being Westfield and Centro - and that demand is going to continue', says Milton Cockburn, executive director of the Shopping Centre Council of Australia.

'That US demand will continue, but if you look ahead to the next ten years, the markets people will be looking at in a much bigger way are the UK and Europe'.

According to Cockburn, a shortage of quality local assets is fuelling the increased push into the UK, but Australia's highly sought-after retailing expertise has facilitated the move.

'Obviously, the fact is shopping centres are very hard to acquire in Australia now, with ownership very tightly held. There's no doubt about that', Cockburn says. 'But I think the Australian shopping model has a lot to offer other countries'.

Because Australia is a relatively small market in terms of numbers of people, Australian centres have evolved into a 'jack of all trades'. Cockburn says Australian shopping centre owners are the most productive per sq $\mathrm{m}$ in the world because of the intensive use of shopping centre floor space. 'In our shopping centres, we typically offer literally the entire shopping experience', he says.

'In many markets it's unusual to find discount department stores in shopping centres, whereas in Australia you go into a major regional 
shopping centre and you will have every range of shopping experience from the supermarkets to the discount department store to the department store'.

Cockburn says this locally developed 'intensive retailing model' is one of the reasons players such as Westfield and Centro have been so successful expanding into overseas markets.

'If you go to the UK and Europe you will still find the shopping centre model there is significantly different to the shopping centre model in Australia', he says. 'If you go to Bluewater, which is one of the premier shopping centres in the UK, you walk around and it's a magnificent experience, but you would not find a fresh food offer and you would not find a discount department store'.

One local player who has put his money where his mouth is in backing Australian retail expertise offshore is Matthew Quinn, managing director of Stockland.

Still digesting the group's $£ 170 \mathrm{~m}(\mathrm{~A} \$ 400 \mathrm{~m})$ takeover of the London Stock Exchange-listed retail and office property development company Halladale Group in February this year, Quinn says there is a lot of experience Australian groups can 'bring to the table' in the UK market.

'From a retail perspective, we've got lot of know-how that we've developed locally, working with brownfield developments, mixed-use developments and also large greenfield sites', he says.

'In the UK there is a lot of rejuvenation of some of the regional towns and, again, we've had experience of that in Australia and we are now looking to put that into the UK market'.

He says one major development the group has in the pipeline in the UK is a large, mixed-use retail rejuvenation project in Birmingham's West Bromwhich.

Quinn says the UK is in a similar position to Australia where market consensus is that yield compression is coming to an end, with prime retail yields in that market 'into the fours'.

'There is a feeling in the UK that retail yields have topped out, so there's not a lot of value to be had in plain vanilla assets - it's about developing and creating value and that's where our group comes in'.

'In the next five years, value in the UK is going to come out of good old-fashioned property skills: development, redevelopment, asset management and forging strong retailer relationships', he says.

Quinn's counterpart in the UK is David Lockhardt, chief executive of Halladale, who will continue to run the group in collaboration with Stockland.

Lockhardt says Halladale's focus in UK retail is in 'convenience shopping' rather than 'comparison shopping'.

'We'll typically buy into first generation shopping centres - underperforming shopping centres - [where] we can apply our asset management and redevelopment skills to upgrade and improve the tenant mix', Lockhardt says.

'The acquisition by Stockland gives us much greater capacity to take on larger projects and, in particular, mixed-use projects, which is going to be very important in the UK going ahead'.

While Stockland plans to continue bolstering its presence in the UK market over the next decade, it will be shopping centre behemoth Westfield Group that will lead the charge. 
In July, Westfield launched a $£ 530 \mathrm{~m}(\mathrm{~A} \$ 1.25 \mathrm{bn})$ wholesale fund in the UK as part of a major expansion, in a move that signals a significant shift in the group's operations.

Westfield has earmarked the UK for its most rapid expansion in the medium term, with plans to grow that business almost 20-fold in the next five to seven years, to about $£ 10$ bn (nearly A\$24bn).

The fund, Westfield UK Shopping Centres Fund, will buy a 25 per cent stake in Westfield shopping centres in Tumbridge Wells, Belfast and Merry Hill. It will also take a quarter stake in Westfield Derby, which is currently under development.

Britain now represents between 15 and 16 per cent of the group's assets, compared with Australia and the US that account for 40 per cent each.

Bill Giouroukos, Westfield's US senior executive vice-president of national marketing, says the shopping centre giant has 59 stores currently operating in the US.

He says Australian real estate trusts are the second biggest overseas investors in US commercial property.

'We're not slowing down, in fact we are continuing to increase our exposure to the US', Giouroukos says. 'We certainly have a commitment to this country'.

According to Giouroukos, Australian groups work well in the US because the two countries have very similar cultures.

'We're not seen as anything that is going to threaten the way they do business here', Giouroukos says.

Westfield has paved the way in the US for fellow Australian retail giant, Centro Properties Group.

Centro is now the fifth largest shopping centre owner and manager in the US, following the US\$3.7bn purchase of the New York-listed New Plan Excel Reality Trust in March.

That deal involved 700 employees and 467 convenience shopping centres across 38 US states, providing Centro with control of about nine million sq $\mathrm{m}$ of retail space.

Andrew Scott, chief executive of Centro, says the weight of local superannuation funds seeking a suitable home and local investors seeking diversification, are the biggest drivers of offshore retail expansion.

'There are masses of superannuation funds, too much arguably to be covered by the Australian assets available', Scott says.

'Unless allocations to property drop massively, there is a need for property investment overseas and that is best reflected by the fact that an estimated 43 per cent of our LPT's assets are in fact overseas assets'.

'Australia represents, in property terms, about 2 percent of the world market for investment grade property. If you want to invest in the other 98 percent you have to invest overseas'.

What can we expect going forward? Scott says the Australian retail invasion in the US - and more importantly the UK - will only pick up pace in the coming 5-10 years.

'While the superannuation system continues with the 9 percent investment requirement for all wage and salary earners, there's significant opportunity there'. 